\title{
Potret Buram Positivisme Hukum: Sebuah Telaah Terhadap Kasus-Kasus Kecil yang Menciderai Rasa Keadilan Masyarakat
}

\author{
Muhammad Azil Maskur, SH., MH. \\ Dosen pada Fakultas Hukum Universitas Negeri Semarang \\ Email: azilmaskur85@mail.unnes.ac.id \\ "Hukum harus dipahami sebagai isntitusi peraturan/undang-undang (normative), institusi \\ sosial (sosiologis), sekaligus juga sebagai institusi keadilan (filosofis)"
}

(Prof. Dr. Satjipto Rahardjo) ${ }^{I}$

\begin{abstract}
The Founding Fathers pada awal kemerdekaan telah menyepakati bentuk negara yaitu negara yang berdasarkan pada hukum (rechstaat). Hal tersebut ditegaskan kembali dalam Undang-Undang Dasar 1945 Amandemen Pasal 1 ayat (3) yang menyatakan bahwa negara Indonesia adalah negara hukum. Hukum disini adalah hukum yang berdasarkan Pancasila, dimana hukum tidak dimaknai sebagai ilmu positivistik belaka akan tetapi lebih pada ilmu tentang kemasyarakatan. Akan tetapi nampaknya pemahaman holistik terhadap hukum dewasa ini sudah keluar dari jalur cita-cita pendirian bangsa ini. Banyaknya kasus yang menciderai rasa keadilan masyarakat seperti kasus minah, kasus manise dan kasus prita yang menyita perhatian publik beberapa waktu yang lalu menjadi potret buram penegakan hukum yang positivistik legalistik. Positivisme hukum seakan menggelinding liar ketengah-tengah pemahaman para aparat penegak hukum yang menciderai rasa keadilan masyarakat. Hukum bukanlah suatu hal yang mati akan tetapi hukum selalu bergerak dinamis dan mengikuti perkembangan zaman. Kasus-kasus kecil seperti kasus minah, manise dan prita adalah contoh kecil dari liarnya penegakan hukum berparadigma positivistik legalistik tanpa ada yang bisa mengendalikan bahkan pemikiran positivistik legalistik ini telah mengakar pada hakim sebagai aparat pemutus pada peradilan. Secara hukum positif, polisi, jaksa, dan hakim tidak dapat dipersalahkan karena hanya memenuhi rumusan Undang-Undang yang tidak memberikan kesempatan pada aparat penegak hukum untuk berbuat sesuai nurani. Walaupun hakim diberi kebebasan sesuai hati nurani akan tetapi apabila terbentur dengan bukti yang sudah lengkap, tidak alas an bagi hakim untuk memutuskan. Disisi lain masyarakat sebagai obyek hukum merasa terusik rasa keadilannya dengan keputusan hakim yang menyatakan minah dan prita bersalah. Sehingga perlu dilakukan upaya penegakan hukum progresif dan dibarengi dengan pembenahan sistem hukum pidana baik dalam segi substansi, struktur maupun budaya hukum.
\end{abstract}

Kata Kunci: Positivisme Hukum, Kasus-Kasus Kecil, Rasa Keadilan Masyarakat

${ }^{1}$ Satjipto Rahardjo dalam Yusriadi, Tebaran Pemikiran Kritis Hukum dan \& Masyarakat, Surya Pena Gemilang: 2011, halaman 32 


\section{A. PENDAHULUAN}

Bangsa Indonesia telah berusia lebih dari setengah abad. Pada awal-awal kemerdekaan The Founding Fathers telah menyepakati bentuk negara yaitu negara yang berdasarkan pada hukum (rechstaat).

Negara Hukum ditegaskan kembali Undang-Undang Dasar 1945 Amandemen Pasal 1 ayat (3) yang menyatakan bahwa negara Indonesia adalah negara hukum.

Perjalanan sebagai negara hukum bangsa Indonesia telah mengalami pasang surut sesuai dengan perkembangan kondisi politik ekonomi bangsa. Sebelum kemerdekaan semua elemen pemuda telah bergabung dalam "sumpah pemuda yang mendeklarasikan bertanah air satu tanah air indonesia, berbangsa satu bangsa indonesia, berbahasa satu bahasa Indonesia. Masa ini adalah masa awal pembentukan negara kesatuan negara republik Indonesia dan sumpah pemuda disepakati dan menjadi dasar hukum pertama dalam sejarah bangsa kesatuan sebelum kemerdekaan. Mungkin ada beberapa hukum tidak tertulis yang berkembang dimasayarakat pada waktu itu, akan tetapi konteksnya belum dalam kesatuan.

Pada saat proklamasi soekarno dan para pendiri bangsa ini memproklamirkan dasar Pancasila. Sebagai negara hukum bangsa ini mengalami masa sulit karena kekuasaan yang mendominasi dan menjadikan hukum sebagai alat kekuasaan yaitu pada zaman orde baru. Hukum tidak punya gigi didepan penguasa orde baru dan siapa yang melawan kekuasaan dialah yang melanggar hukum. Pada masa ini banyak terjadi kasus yang tak terungkap, seperti kasus pembunuhan marsinah (aktivis buruh), pembunuhan masal di Tanjung Priok, dan banyak kasus korupsi, kolusi dan nepotisme yang dilakukan penguasa orde baru tidak dapat ditindak didepan hukum.

Ketidakberdayaan hukum tersebut menjadikan rakyat ini geram dan akhirnya menurunkan rezim orde baru dan bergulir reformasi. Saat reformasi ini hukum seperti mendapat angin segar, hukum kembali didengungkan oleh rakyat Indonesia sebagai panglima dan harus ditegakkan. Semangat untuk membatasi kekuasaan dengan hukum ini diimplementasikan dengan pemilihan umum Tahun 1999, dan amandemen UUD 1945 oleh MPR hasil pemilihan umum Tahun 1999. Melihat pasang surutnya perjalanan hukum tersebut, maka sangat tepat jika dikatakan bahwa hukum dipengaruhi oleh faktor-faktor sosial lain disekitarnya dan hukum tidak dapat dilepaskan dari realitas sosial yang melingkupinya 2. Masalah sosial yang melingkupi ini sekarang sedang menajdi pembicaraan para penstudi hukum tidak hanya ditanah air, akan tetapi juga di dunia.

\footnotetext{
2 Esmi Warassih, Pranata Hukum Sebuah Telaah Sosiologis, Badan Penerit Undip: 2011, hal. 7
} 
Pengaruh sosial dalam hukum tidak hanya nampak jika hukum dilihat dari kacamata makro dalam ranah kebangsaan, akan tetapi juga sangat nampak pada hukum ketika menghadapi kasus-kasus mikro tertentu, baik dalam ranah hukum pidana, perdata maupun tata negara. Dalam suatu sengketa yang menggunakan hukum sebagai tempat penyelesaian melalui lembaga hukum sangat kental dengan pengaruh sosial yang melingkupi. Pengaruh sosial ini ada yang menjadikan dampak positif juga ada yang menjadikan dampak negatif. Sebagai contoh kasus prita yang divonis bersalah dengan putusan Mahkamah Agung, dan bahkan kasus pencurian listrik, kasus minah, kasus pencurian semangka dan kasus-kasus yang lain.

Mendalami apa yang terjadi dengan kasus-kasus di atas sangat menarik, apalagi apabila kasus-kasus kecil ini disandingkan dengan kasus-kasus besar seperti kasus korupsi para bupati, kasus mafia pajak gayus tambunan, kasus suap hakim syarifudin dan kasus-kasus lain yang merugikan negara miliaran rupiah. kasus minah, kasus pencurian semangka di Kediri, kasus pencurian listrik di Jakarta, kasus prita di tangerang, mungkin bisa menjadi contoh kasus yang bisa dijadikan kajian untuk mewakili kasus-kasus yang dianggap kecil akan tetapi hukum tetap jalan sesuai yang digariskan dalam peraturan perundang-undangan, dan sandingannya adalah kasus-kasus besar seperti kasus gayus tambunan, kasus korupsi wisma atlet.

Permasalahan yang diangkat dalam tulisan ini adalah (1) bagaimana hukum positif di Indonesia memandang kisah kasus-kasus kecil seperti kasus minah, kasus prita; (2) bagaimana pandangan masyarakat terhadap kasus minah, kasus prita; dan (3) bagaimana solusi penegakan hukum terhadap kasus prita dan kasus minah. Pada tulisan ini juga akan membahas lebih jauh dari ketidakseimbangan hukum positif dalam menyelesaikan perkara tersebut, seperti hukum positif di Indonesia memandang kisah kasus-kasus kecil seperti kasus minah, kasus prita, selanjutnya juga akan dibahas pandangan masyarakat terhadap kasus minah, kasus prita, serta solusi penegakan hukum terhadap kasus prita dan kasus minah.

\section{B. PEMBAHASAN}

Definisi hukum sangat luas dan kompleks serta tergantung dari siapa yang mendefinisikan. Hal ini menyebabkan hukum seaka-akan definisi hukum (pembatasan pengertian hukum) adalah suatu yang non definisi (tanpa batas). Akan tetapi perlu diberikan definisi hukum yang diharapkan akan mewakili dari berbagai pandapat para ahli. Menurut Soerjono Soekanto dalam Esmi Warassih mengemukakan bahwa hukum dapat 
diartikan menjadi 9 (Sembilan) pengertian yaitu3: (1) hukum diartikan sebagai ilmu, pengertian ini memandang bahwa hukum itu mempunyai sifat dan metode sebagaimana dimiliki oleh ilmu pada umumnya yang merupakan bagian dari pengetahuan yang melalui proses epistemologis ${ }^{4}$; (2) hukum sebagai disiplin atau sistem ajaran tentang kenyataan, dalam hal ini hukum dipandang sebagai suatu realitas sosial nyata yang melingkupi perjalanan manusia; (3) Hukum diartikan sebagai kaedah atau norma, pengertian ini yang sering muncul yaitu hukum tak ubahnya adalah suatu rangkaian peraturanperaturan atau norma-norma yang harus dipatuhi oleh wilayah yang menjadi bagiannya, (4) Hukum dalam arti tata hukum atau hukum positif tertulis, pengertian ini sebagaimana yang dianut faham positivistik legalistik yang memandang hukum adalah suatu peraturan yang tertulis (scripta); (5) Hukum diartikan sebagai keputusan pejabat, hal ini mengandung pemahaman bahwa apa yang diputuskan oleh pejabat yang berwenang merupakan suatu hukum yang harus ditaati oleh setiap warga negara; (6) hukum dalam arti petugas, definisi ini memberikan pengertian bahwa hukum adalah petugas atau aparat, jadi apa yang keluar dari aparat

${ }^{3}$ Esmi Warassih, Pranata Hukum Sebuah Telaah Sosiologis, Badan Penerit Undip: 2011, hal. 17- 18

${ }^{4}$ Maman Rachman dkk, Filsafat Ilmu, UPT MKU Universitas Negeri Semarang: 2003, hal. 101 merupakan hukum; (7) hukum yang diartikan sebagai proses pemerintahan, yaitu setiap proses dalam menjalankan pemerintahan merupakan bagian yang tak terpisahkan dari hukum; (9) hukum diartikan sebagai jalinan nilai, definisi ini yang paling tinggi filosofinya karena menganggap bahwa hukum adalah perwujudan dari nilai seperti nilai keadilan, nilai keseimbangan, nilai kebaikan, nilai keteraturan dan nilia-nilai luhur yang lain.

Dari pendapat di atas, dapat dikatakan bahwa hukum mencakup segala aspek kehidupan manusia, sehingga sangat luas. Akan tetapi menurut Prof. Satjipto Rahardjo membatasi pengertian hukum menjadi 3 (tiga) kelompok pengertian dasar, yaitu 5 : pertama, hukum sebagai perwujudan ide atau nilai-nilai-nilai tertentu; kedua, hukum sebagai suatu sistem peraturan yang abstrak; ketiga, hukum dipandang sebagai sarana untuk mengatur masyarakat (social control).

Hukum dapat dilihat dari berbagai sudut pandang. Dari pemberlakuan hukum hukum dibagi menjadi dua (2) yaitu: (1) hukum positif (ius constitutum) dan (2) hukum yang dicita-citakan (ius constituendum), dari objeknya hukum dapat dibedakan menjadi hukum privat dan hukum public, dari obyeknya ini hukum dapat dibedakan lagi menjadi bermacammacam ranah yaitu: hukum pidana, hukum

${ }^{5}$ Satjipto Rahardjo, Ilmu Hukum, Penerbit Alumni: 1986, hal. 6 
perdata, hukum tatanegara, hukum internasional, hukum dagang, hukum perusahaan, hukum ekonomi, hukum teknologi dan lain-lain yang lebih spesifik.

Hukum sebagai sebuah ilmu juga telah terbelah dari berbagai aliran-aliran sudut pandang, menurut Prof. Yusriadi, setidaknya ada 3 (tiga) metode pendekatan dalam ilmu hukum yang kemudian memunculkan 3 aliran dalam ilmu hukum, yaitu6: (1) pendekatan yuridis dogmatis yaitu suatu cara pendekatan yang menggunakan logika akal untuk mengolah pasal-pasal dalam peraturan, sehingga pengertian-pengertian yang dihasilkan dalam penerapan hukum sering mengabaikan kenyataan dan keadilan karena kepastianlah yang diutamakan, (2) pendekatan kausal empiris/sosiologis yaitu pendekatan yang menggunakan konsep sebab akibat dalam mempelajari hukum, sehingga pasal-pasal dalam aturan hukum akan dipelajari berdasarkan hukum sebabakibat, (3) filosofis/idealis/ideologis yaitu metode pendekatan yang melihat peraturanperaturan hukum dalam pasal-pasal dengan ide-ide dasar yang luhur yang jauh melatarbelakangi terbentuknya hukum tersebut, seperti nilai keadilan, nilai kemnafaatan, nilai keseimbangan.

Hukum diciptakan oleh manusia mempunyai tujuan tertentu. Untuk

\footnotetext{
${ }^{6}$ Yusriadi, Tebaran Pemikiran Kritis Hukum dan \& Masyarakat, Surya Pena Gemilang: 2011, halaman 7.
}

mengetahui tujuan hukum maka dapat diatarik dari nilai-nilai yang hendak diwujudkan oleh hukum yaitu nilai kepastian, nilai keadilan dan nilai kemanfaatan. Prof. Yos Yohan Utama ${ }^{7}$ menambahkan nilai kasih sayang dan Prof. Barda Nawawi Arif $^{8}$ menambahkan nilai keseimbangan dalam hukum. Dari nilai dasar itu tentunya dapat ditarik tujuan dari hukum yaitu untu mencapai kepastian huku, untuk mencapai keadilan, untuk membawa kemanfaatan bagi segenap lapisan masyarakat, untuk menciptakan kasih saying antar makhluk hidup, dan untuk menjaga keseimbangan dunia.

Prof. Esmi Warassih mengemukakan 3 (tiga) tujuan hukum, yaitu': Pertama Hukum bertujuan untuk menemukan suatu keadilan, atau yang disebut dengan teori etis. Penganutnya antara lain: genry. Dalam hal ini hukum dipandang sebagai perwujudan nilai keadilan sehingga sudah sepatutnya kembali pada tujuan keadilan yang sebenarnya. Aristoteles membagi keadilan menjadi 2 (dua) yaitu keadilan distributive (keadilan yang sesuai dengan haknya) dan keadilan commutative (keadilan yang menitikberatkan pada

\footnotetext{
${ }^{7}$ Disampaikan dalam kuliah materi
} Hukum Administrasi Negara pada Magister Hukum Undip, Semarang, 2011.

${ }^{8}$ Disampaikan dalam kuliah materi Politik Hukum Pidana pada Magister Hukum Undip, Semarang, 2011.

${ }^{9}$ Esmi Warassih, Pranata Hukum Sebuah Telaah Sosiologis, Badan Penerit Undip: 2011, hal. 19-20. 
kesamaan jumlah yang didapat setiap orang).

Kedua, hukum bertujuan untuk menjamin kebahagiaan sebesar-besarnya bagi manusia (the greteast happiness of the greatest number). Tujuan ini menitikberatkan pada kemanfaatan bagi orang banyak, sehingga yang diutamakan adalah kuantitas yang diharapkan mendapat kemanfaatan bukan suatu minoritas atau suatu kelompok kecil tertentu, pandangan ini dikenal dengan teori utilitas.

Ketiga, Hukum bertujuan menciptakan ketertiban. Hal ini dikenal dengan teori campuran. Hukum dipandang memiliki kekuatan yang besar untuk mengatur manusia dengan sifatnya yang memaksa, sehingga akan mencapai sebuat masyarakat yang tertib dan pada akhirnya akan menciptakan masyarakat yang teratur.

\section{Pandangan Hukum Positif terhadap Kasus Minah dan Prita}

Pandangan hukum positif adalah sebuah pandangan yang dianut dalam bangsa ini dalam berhukum sehingga hanya berpedoman dengan apa yang ditulis dalam suatu peraturan semata. Di awal telah dijelaskan aliran-aliran dalam ilmu hukum yang mempengaruhi cara pandang aparat penegak hukum dalam menafsirkan suatu aturan. Pandangan positivistik yang dianut sebagian besar aparat penegak hukum bangsa ini dilatarbelakangi oleh pendekatan yuridis dogmatic dalam menelaah hukum.
Hukum hanya merupakan olahan dan ramuan peraturan-peraturan yang tertulis yang dilakukan oleh akal manusia sehingga mengakibatkan logika yang hanya bermain dalam hukum dan mengabaikan kenyataan dan keadilan. Dalam pandangan ini, apa yang tertulis itulah yang merupakan keadilan.

Sebelum menganalisa pandangan hukum positif terhadap kasus-kasus kecil seperti minah, prita, dan pencurian semangka, maka penulis akan mencoba memulai dari perjalanan kasus tersebut.

\section{Kasus Prita}

Menurut beberapa sumber media dapat dijelaskan kronologis Prita Mulyasari diawali pada tanggal 7 Agusutus 2008, Prita Mulyasari memeriksa kesehatan bertempat di Rumah Sakit Omni Internasional Tengerang - Banten. Prita Mulyasari mengeluhkan panas tinggi dan pusing kepalA, Prita Mulyasari ditangani dr. Indah dan dr. Hengky, dari diagnosa menunjukkan bahwa Prita Mulyasari menderita demam berdarah, dan disarankan rawat inap.

Pada tanggal 8 Agustus 2008, Prita Mulyasari dikunjungi dr. Hengky dan memberikan kabar tentang perubahan thrombosit dari sebelumnya 27.000 menjadi 181.000. dan Prita Mulyasari pada hari itu diberi banyak suntikan, tanpa pemberitahuan jenis dan tujuan penyuntikan; akan tetapi tak lama berselang mulai terliat kejanggalan pada badan Prita 
Mulyasari yakni; tangan kiri membengkak, suhu badan naik hingga mencapai 39 derajat; Tanggal 9 Agusustus 2008, Prita Mulyasari dikunjungi dr. Hengky dan meninginformasikan kepada pasien bahwa dirinya terkena virus udara. Sejauh ini, tindakan medis berupa suntikan terus diberikan ketubuh Prita Mulyasari, apda hari yang sama sehabis maghrib, Prita Mulyasari disuntik 2 ampul dan terserang sesak napas selama 15 menit dan diberikan oxygen. Saat yang sama hadir dokter jaga tanpa dr. Hengky. Saat yang sama tangan kanan Prita Mulyasari mengalami pembengkakan. Prita Mulyasari meminta infus dan suntikan serta obat-obatan dihentikan.

Kemudian pada tanggal 10 Agustus 2008, keluarga Prita Mulyasari meminta ketemu dr. Hengky dan meminta penjelasan tentang kondisi dan keadaan pasien termasuk penjelasan tentang revisi hasil lab. Saat yang sama, Prita Mulyasari mengalami pembengkakan di leher kiri dan mata kiri. Respon dr. Henky lebih menyalahkan bagian lab. Tanggal 11 Agustus 2008, Prita Mulyasari masih panas tinggi mencapai 39 derajat. Prita Mulyasari berniat pindah dan pada saat yang sama Prita Mulyasari membutuhkan data medis. Setelah sampai ke tingkat manajemen RS Omni, data Prita Mulyasari diprint out tanpa diserta data hasil lab yang valid. Pada tanggal 12 Agustus 2008, Prita Mulyasari pindah ke RS lain di Bintaro. Disini Prita Mulyasari dimasukkan ruang isolasi oleh karena virus yang menimpa dirinya dapat menyebar. Menurut dokter, Prita Mulyasari terserang virus yang biasa menyerang anak-anak. (disini fakta Prita Mulyasari terserang demam berdarah tidak terbukti, hanya saja Prita Mulyasari telah terlanjur disuntik bertubi-tubi ditambah infus di RS Omni); pada tanggal yang sama, keluarga Prita Mulyasari meminta hasil resmi kepada RS. Omni tentang hasil lab yang semula 27.000 dan berubah menjadi 181.000 (Thrombosit rendah mengharuskan pasien rawat inap).

Pada tanggal 15 Agustus 2008, Prita Mulyasari menulis dan mengirimkan email pribadi kepada terdekat terkait keluhan pelayanan RS Omni internasional. Email ini kemudian beredar luas di dunia maya; sesaat setelah menyebar ke dunia maya, RS omni tidak terima akan tetapi ada upaya mediasi antara Prita Mulyasari dan RS Omni, hanya saja mengalami kebuntuan, Pada tanggal 6 September 2008, dr. Hengky menggugat Prita Mulyasari dan masuk dalam kategori gugatan pidana (pencemaran nama baik); Pada tanggal 8 September 2008, pihak Omni Internasional menanggapi email Prita Mulyasari di harian Kompas dan Media Indonesia; Pada tanggal 24 September 2008, Prita Mulyasari menggugat perdata RS Omni termasuk dr. Hengky dan dr. Grace; Pada tanggal 11 Mei 2009, Prita Mulyasari diputuskan kalah dalam kasus perdata, konsekuensinya Prita Mulyasari harus membayar ganti rugi 
materiil $\mathrm{Rp} 161$ juta dan kerugian immaterial Rp 100 juta

Pada tanggal 13 Mei 2009, Prita Mulyasari ditahan di LP Wanita Tangerang, sebagai tahanan kejaksaan; Pada tanggal 12 Juni 2009, Prita Mulyasari kebanjiran pendukung khususnya dari para blogger hingga mencapi 30.000. Pada anggal 3 Juni 2009, kasus Prita Mulyasari meminta perhatian publik pada skala massif. Dukungan pun datang hingga RI 1 dan RI 2 turun tangan. Lebih dari itu, dukungan para blogger mencapai angka 40.000, ditambah suara LSM, akademisi, politisi bersatu membuat opini publik, tidak seharusnya Prita Mulyasari ditahan dan harus segera dibebaskan. 3 Juni 2009, tepat pukul 16.20 Prita Mulyasari dibebaskan dari LP Wanita Tangerang dengan perubahan status sebagai tahanan kota.

Mulai tanggal 4 Juni 2009, Prita Mulyasari sidang dalam perkara pidana. Pada 29 Desember 2009 majelis hakim Pengadilan Negeri Tangerang memutuskan bebas atas Prita dari tuntutan jaksa dengan dakwaan pencemaran nama baik Rumah Sakit (RS) Omni Internasional tidak terbukti secara sah dan meyakinkan yang sebelumnya Prita diwajibkan membayar uang ganti rugi sebesar Rp 204 juta kepada RS Omni Internasional

Jaksa mengajukan Kasasi ke MA dan MA mengabulkan kasasi jaksa. majelis kasasi Mahkamah Agungmengeluarkan keputusan dalam putusan perkara bernomor
822 K/PID.SUS/2010, telah membatalkan vonis bebas Prita Mulyasari dalam kasus pencemaran nama baik RS Omni Internasional. Vonis 6 bulan penjara dengan 1 tahun masa percobaan dikukuhkan oleh hakim lembaga peradilan tertinggi itu ${ }^{10}$.

\section{Kasus Mbah Minah}

Kasus ini berawal dari nenek minah yang karena ketidaktahuannya dan buta huruf, mengambil 3 buah biji kakau yang terjatuh dari pohonnya di perkebunan PT. Rumpun Sari Antan untuk dibawa pulang dan dijadikan benih. Saat buah itu diletakkan di tanah, ia kemudian melanjutkan pekerjaanya membersihkan ilalang di kebun kakao. Ketika mandor kebun melihat ada 3 buah kakau maka mencari siapa yang mengambil, dan diketahui bahwa nenek minahlah yang mengambil akan tetapi begitu mandor menuduh nenek minah mencuri, nenek minah langsung minta maaf dan mengembalikan kakau tersebut, konon 3 buah biji kakau tersebut senilai 30.000, akan tetapi sumberlain ada yang mengatakan perbiji Rp.6000,-. Mandor perusahaan tidak memperdulikan permintaan maaf nenek minah dan tetap memprosesnya ke pihak yang berwajib kepolisian dengan alasan supaya tidak mengulangi perbuatannya lagi dan menjadikan efek jera (pencegahan) bagi masyarakat yang berniat berbuat sama.

\footnotetext{
${ }^{10}$ Sumbawanews.com dan detiknews.com, diunduh pada tanggal 20 Juli 2011.
} 
Perjalanan kasus ini menjadi aneh ketika mandor kebun membawa $3 \mathrm{Kg}$ buah kakau ke kejaksaan negeri sebagai barang bukti, sehingga kejaksaan negeri purwokerto menetapkan penahanan rumah selama 3 bulan dan pada akhirnya pengadilan negeri memutus nenek minah bersalah dengan dijatuhi pidana percobaan 1 bulan 15 hari dengan masa percobaan ${ }^{11}$.

Melihat duduk perkara kasus tersebut maka dalam pandangan hukum positif nenek minah dapat terbukti telah mencuri 3 buah biji kakau, sehingga menurut pandangan KUHP apa yang telah dilakukan telah memenuhi unsur sebagaimana yang tersebut dalam Pasal 362 KUHP, yang berbunyi ${ }^{12}$ :

"Barangsiapa mengambil barang sesuatu, yang keseluruhannya atau sebagian kepunyaan orang lain, dengan maksud untuk dimiliki secara melawan hukum, diancam karena pencurian, dengan pidana penjara paling lama lima tahun atau denda paling banyak enampuluh rupiah “

Rumusan pasal ini jika digunakan sebagai dasar untuk menindak mbah minah oleh siapa saja yang berkepentingan seperti mandor kebun, polisi, dan jaksa sangat

11

http://www.detiknews.com/read/2009/11/20/135 420/1245643/10/menkum-ham-kasus -nenek-minah-memalukan, diunduh pada tanggal 1 Mei 2016

${ }^{12}$ Moelyatno, 2009, Kitab UndangUndang Hukum Pidana, Bumi Aksara, Jakarta, hal. 128 tepat. Hal ini bisa dijelaskan bahwa dalam rumusan pasal di atas ada unsur yang harus dibuktikan oleh aparat penegak hukum, yaitu: (1) barangsiapa, (2) mengambil barang secara keseluruhan atau sebagian, (3) kepunyaan orang lain, (4) dengan maksud untuk dimiliki secara melawan hukum. Ke empat unsur ini terbukti dalam kasus mbah minah ini.

Sedangkan untuk kasus prita mulyasari, telah melanggar Pasal 27 ayat (3) yaitu prita mulyasari karena dianggap telah terbukti dengan sengaja dan tanpa hak mendistribusikan danatau mentransmisikan danatau membuat dapat diaksesnya Informasi Elektronik danatau Dokumen Elektronik yang memiliki muatan penghinaan dan/atau pencemaran nama baik. Sehingga dengan pandangan hukum positif yang dianut oleh bangsa ini tidak bisa tidak ketika ada sesorang yang telah melakukan tindak pidana artinya melanggar aturan pidana dalam sebuah pasal KUHP, terhadapnya akan diproses secara hukum.

Pihak kepolisian yang merupakan pintu gerbang pertama dalam penindakan terhadap perlakuan warga negara yang diduga melakukan tindak pidana dalam arti memenuhi rumusan pidana (KUHP) akan serta merta menjalankan tugasnya sebagai lembaga penyidikan. Hal ini sesuai dengan Pasal 7 Kitab Undang-Undang Hukum Acara Pidana yaitu: "Penyidik sebagaimana dimasksud dalam Pasal 6 ayat (1) huruf a karena kewajibannya mempunyai 
wewenang: (a) manerima laporan atau pengaduan dari seseorang tentang adanya tindak pidana; (b) melakukan tindakan pertama pada saat ditempat kejadian; (c) menyuruh berhenti seseorang tersangka dan memeriksa tanda pengenal diri tersangka, (d) melakukan penangkapan, penahanan, penggeledahan, dean penyitaan; melakukan pemeriksaan dan penyitaan surat, (f) mengambil sidik jari dan memotret seseorang; (g) memanggil orang untuk didengar dan diperiksa sebagai tersangka atau saksi, (h) mendatangkan orang ahli yang diperlukan dalam hubungannya dengan pemeriksaan perkara;

(i) Mengadakan pengehentian penyidikan,

(j) mengadakan tindakan lain menurut hukum yang bertanggungjawab."

Hukum bangsa ini masih menggunakan KUHP yang didalamnya mengandung asas legalitas, yaitu Pasal 1 ayat 1 KUHP. Artinya dianggap sebagai tindak pidana apabila memenuhi rumusan undang-undang yang ada sebelum perbuatan dilakukan. Asas legalitas ini jelas mengidentifikasikan perbuatan nenek minah dan prita ini sebagai tindak pidana karena memenuhi rumusan undang-undang dan KUHP telah ada sebelum perbuatan dilakukan.

Sehingga dapat dikatakan bahwa perbuatan nenek minah dan kasus prita ini apabila dilihat dari sudut pandang hukum positif ansih dan parsial tentu semua ahli hukum dapat menjawab bahwa perbuatannya melanggar aturan pidana sehingga patut di pidana. Permasalahan berapa pidana yang akan dijatuhkan nantinya tergantung hakim. Hakim akan menjatuhkan putusannya tergantung dari hasil persidangan berdasarkan alat bukti yang ada dan kenyakinan hakim.

Melalui pasal-pasal yang digunakan terhadap nenek minah dan prita tersebut, akhirnya secara ketentuan KUHAP, yang bersangkutan yaitu Prita Mulyasai dan nenek minah telah melakukan tindak pidana yang dapat ditahan karena telah memenuhi rumusan KUHAP sebagai tindak pidana yang dapat dilakukan penahanan. Seperti diketahui, pasal 7 ayat (1) butir dan pasal 20 ayat (1) UU No. 8 Tahun 1981 tentang Hukum Acara Pidana (KUHAP) memberi kewenangan kepada penyidik untuk menahan tersangka yang diduga melakukan tindak pidana berdasarkan bukti yang cukup. Selain penyidik, dalam pasal 20 ayat (2) dan (3) penuntut umum dan hakim juga berwenang menahan tersangka/ terdakwa.

Syarat penahanan juga sudah ditentukan secara limitatif yaitu syarat subjektif, yaitu ada kekhawatiran tersangka melarikan diri, merusak/ menghilangkan barang bukti dan atau mengulangi tindak pidana (Pasal 20 ayat 1). Dan Syarat objektif, syarat ini berkaitan dengan penahanan dikenakan terhadap tindak pidana yang diancam dengan pidana penjara 5 tahun atau lebih dan pasal-pasal tertentu dalam KUHP maupun diluarnya 
yang ditentukan pasal 21 ayat 4 butir b yaitu tindak pidana yang tergolong Pasal 282 ayat (3), Pasal 296, Pasal 335 ayat (1), Pasal 351 ayat (1), Pasal 353 ayat (1), Pasal 372, Pasal 378, Pasal 379 a, Pasal 453, Pasal 454, Pasal 455, Pasal 459, Pasal 480 dan Pasal 506 Kitab Undang-undang Hukum Pidana, Pasal 25 dan Pasal 26 Rechten ordonnantie (pelanggaran terhadap Ordonansi Bea dan Cukai, terakhir diubah dengan Staatsblad Tahun 1931 Nomor 471), Pasal 1, Pasal 2 dan Pasal 4 Undangundang Tindak Pidana Imigrasi (Undangundang Nomor 8 Drt. Tahun 1955, nLembaran Negara Tahun 1955 Nomor 8), Pasal 36 ayat (7), Pasal 41, Pasal 42, Pasal 43, Pasal 47 dan Pasal 48 Undang-Undang Nomor 9 Tahun 1976 tentang Narkotika (Lembaran Negara Tahun 1976 Nomor 37, Tambahan Lembaran Negara Nomor 3086).

Kasus nenek minah ini telah dijatuhi vonis oleh hakim yaitu penjara 1,5 bulan dengan masa percobaan 3 bulan. Sedangkan kasus prita telah diputus oleh Mahkamah Agung dengan pidana 6 bulan penjara dengan 1 tahun masa percobaan. Dengan adanya putusan ini walaupun kedua terdakwa tidak usah menjalani hukumannya karena hanya pidana percobaan, akan tetapi dalam diri nenek minah dan prita apa yang dilakukannya tetap dikatakan suatu tindak pidana dan bersalah. Inilah hukum positif yang berlaku di begeri ini.

\section{Pandangan Masyarakat Terhadap Kasus Minah dan Kasus Prita}

Kasus prita dan kasus minah hanya sebagian kecil dari kasus-kasus serupa yang pada akhirnya dibawa ke meja hijau, tengok saja kasus pencurian semangka, kasus pencurian listrik, kasus pencurian bijih kapas randu, dan kasus-kasus lain.

Banyak pihak yang memandang hukum di negara ini masih terkesan tebang pilih, meminjam bahasanya prof. Yusriadi; hukum runcing kebawah dan tumpul ke atas. Runcing kebawah karena selama ini apabila hukum mengenai obyek rakyat kecil, maka hukum akan tegas bak pedang yang tajam. Sehingga hukum positif akan dijalankan dengan segera tanpa melihat sosio histori dari perbuatan yang dianggap tindak pidana. Sedangkan apabila hukum mengenai pejabat tinggi ataupun konglomerat sekelas nazarudin, nunun nurbaeti, dan pejabat-pejabat lain, hukum terkesan loyo bak pedang yang sudah berkarat sehingga sekeras apapun pedang itu diancamkan tidak akan mempan.

Keadaan yang seperti itu tentunya bukan hukumnya atau aturannya saja yang dipersalahkan akan tetapi lebih pada aparat penegak hukumnya yang masih kadangkadang kehilangan moral, tengok saja kasus suap hakim syarifudin dan kasus suap jaksa urip yang menandakan aparat penegak hukum masih menggadaikan kebenaran, keadilan demi sejumlah uang. Dari 
beberapa media cetak maupun elektronik dapat diketahui bahwa animo masyarakat terhadap terhadap kasus-kasus yang menyentuh rasa keadilan masyarakat ini sangat tinggi.

Salah satunya datang dari anggota Dewan Pers Edmon Makarim yang berpendapat dalam persoalan Prita, menurutnya dalam kasus prita yang terjadi adalah kesalahan penerapan Pasal 27 ayat (3) UU ITE. Perbuatan pencemaran nama baik tidak seharusnya diterapkan dalam kasus prita karena, perbuatan prita ini dilindungi oleh Undang-Undang perlindungan Konsumen, karena pasal 27 ayat (3) UU ITE multitafsir mengakibatkan Prita menjadi korban ${ }^{13}$.

Bahkan ketika prita di vonis perdata oleh Pengadilan Tinggi Banten dengan denda 204 Juta, masyarakat yang merasa keadilan terusik dengan vonis tersebut spontan masyarakat menanggapi dengan mengumpulkan koin (uang recehan) yang nantinya akan diserahkan ke RS omni ${ }^{14}$.

Rasa terusik hati masyarakat terlihat ketika pengumpulan koin tersebut terakhir koin uang recehan yang terkumpul di posko pusat koin peduli prita di Jakarta mencapai 825 Juta, dengan perincian dua Posko Keadilan di Jakarta terkumpul koin

\footnotetext{
${ }^{13}$ http://dewanpers.or.id/kegiatan/ berita/ 768- pasal- defamasi- rentan- disalahgunakan.

${ }^{14}$ http:// majalah.tempointeraktif.com/id/arsip/2009/12/1 4/OPI/mbm.20091214.OPI132202. id.html, diunduh tanggal 26 Juli 2011.
}

Rp612.998.550,-, sumbangan berupa uang kertas Rp55 juta, uang yang dikirimkan melalui paket dari beberapa daerah Rp37 juta, dan sumbangan dari mantan Menteri Perindustrian Fahmi Idris Rp102 juta, sumbangan dari pengunjung Hard Rock Cafe Rp15.800.000 serta penjualan kaos Konser Koin untuk Keadilan "Free Prita" Rp2.280.000 ${ }^{15}$.

Dalam kasus minah, menteri Hukum dan HAM Patrialis akbar merasa prihatin tentang vonis 1,5 bulan yang dijatuhkan ke nenek minah ${ }^{16}$. Para penegak hukum memang sudah seharusnya mempunyai prinsip kemanusiaan, bukan hanya menjalankan hukum secara positifistik. Bahkan hakim yang menangani kasus nenek minah tidak bisa berbuat apa-apa, karena bukti sudah dianggap lengkap. Hakim sampai menangis ketika membacakan vonis untuk kasus minah. Banyak lagi pendapat yang miris melihat kasus-kasus kecil seperti ini sampai ke Pengadilan.

Pandangan-pandangan masyarakat tersebut mengindikasikan bahwa kasuskasus ini sangat tidak adil, aparat penegak hukum hanya mengejar kepastian dan mengabaikan nilai-nilai yang lain yaitu keadilan, kemanfaatan. Padahal hukum

15 http://news.okezone.com/ read/2009/12/21/338/286733/ koin-untuk-pritaterkumpul-rp825-juta, diunduh tanggal 26 Juli 2011.

${ }^{16} \mathrm{http}: / /$

www.detiknews.com/read/2009/11/20/135420/1 245643/10/menkum-ham-kasus-nenek-minahmemalukan, diunduh tanggal 26 Juli 2011. 
adalah ramuan antara nilai-nilai kepastian, kemanfaatan, dan keadilan ${ }^{17}$.

$$
\text { Akan tetapi para aparat penegak }
$$
hukum seakan-akan takut untuk menemukan hukum karena paradigm positivistik sudah kental dan membuat aparat takut untuk berbuat diluar apa yang digariskan. Disinilah positivistik akhirnya bisa dianggap sebagai bola liar yang akan menerpa siapa saja dan tidak ada yang bisa mengendalikan karena apabila nekat mengendalikan bayangan menyalahi aturan atau melanggar hukum selalu menghantui.

\section{E. Penegakan Hukum Progresif sebagai Solusi}

Persoalan-persoalan yang terjadi seperti kasus minah dan prita membuat rasa keadilan masyarakat terganggu sehingga diperlukan suatu pendekatan penegakan hukum yang relevan. Penegakan Hukum menurut Prof. Satjipto Rahardjo adalah suatu proses untuk mewujudkan keinginankeinginan hukum menjadi kenyataan. Dalam penegakan hukum maka persoalan yang sering muncul adalah berkaitan nilai apa yang akan utamakan, apakah nilai kepastian hukum, nilai keadilan atau nilai kemanfaatan. Ketiga nilai ini yang sering bersitegang satu sama lain. Mementingkan satu nilai akan mengorbankan nilai yang lain. Terutama nilai keadilan yang

${ }^{17}$ Yusriadi, Tebaran Pemikiran Kritis Hukum dan \& Masyarakat, Surya Pena Gemilang: 2011, halaman 9 merupakan nilai tertinggi dari hukum dan sudah semestinya di tegakkan ${ }^{18}$.

Nilai keadilan ini sering bertabrakan dengan nilai kepastian aan tetapi nilai keadilan tidak semestinya dikorbankan demi mengejar kepastian karena hal itu akan membuat hukum kehilangan ruhnya dan hukum semakin jauh dari harapan masyarakat. Roberto M. Unger ${ }^{19}$ mengatakan semakin keadilan dikorbankan demi logika peraturan, semakin lebar jarak antara hukum pemerintah dan sentimen akan kebenaran, akibatnya hukum kehilangan kejernihannya, juga legitimasinya di mata orang awam. Yang dimaksud unger disini keadilan substansial tentunya. Penegakan hukum pada hakikatnya tidak terbatas hanya pada sisi penerapan aturan, akan tetapi lebih jauh dari itu bahwa penegakan hukum telah dimulai dari tahap pembuatan undangundang (legislasi), tahap penerapan hukum (aplikasi/yudicial) serta tahap pelaksanaan putusan pengadilan (eksekusi/administrastif) $^{20}$. Dalam setiap tahapan inilah proses penegakan hukum dilaksanakan.

18 Satjipto Rahardjo dalam Ali Masyhar, Pergulatan Kebijakan Hukum Pidana dalam Ranah Tatanan Sosial, Unnes Press: 2008, halaman 5

19 Roberto M. Unger, 2010, Teori hukum Kritis, Penerbit Nusa Media, Bandung, hal. 270-271

${ }^{20}$ Ali Masyhar, Pergulatan Kebijakan Hukum Pidana dalam Ranah Tatanan Sosial, Unnes Press: 2008, halaman 5 
Kasus-kasus seperti minah dan prita adalah contoh kecil dari ketidakberdayaan aparat terhadap positivisme hukum yang dianut bangsa ini, sehingga positivisme tersebut bak bola liar yang akan mengenai siapa saja. Hal ini terlihat ketika hakim pada sidang vonis minah sampai menangis ketika membacakan putusan. Pada diri haki tersebut tersirat upaya ketidaksetujuannya akan putusan yang dijatuhkannya sendiri akan tetapi seakan-akan hakim tidak menemukan solusi untuk membebaskan minah dari jeratan hukum karena proses sudah berjalan dan kenyataan bukti sudah lengkap. Apabila dikaji lebih mendalam sebenarnya hakim mempunyai kewenangan yang mutlak untuk menjatuhkan vonis sesuai dengan kenyakinannya. Hal yang demikian ini pernah dicontohkan oleh hakim bismar siregar yang mengatakan bahwa dalam ruang sidang ini, sayalah (bismar) ndang-undang. Hakim yang berani menafsirkan hukum sendiri seperti ini nampaknya jarang sekali ditemui di negeri ini.

Jembatan penguhubung yang dapat menghubungkan antara kepastian hukum dan keadilan serta kemanfaatan dalam penegakan hukum adalah meramu ketiganya. Akan tetapi tidak mudah mudah meramu ketiga nilai tersebut karena mempunyai hubungan ketegangan. Hal ini akan terpecahkan ketika menggunakan pandangan hukum progresif yang digagas oleh Satjipto rahardjo. Konsep Penegakan hukum progresif sangat relevan untuk emmbenahi sistem hukum di indonesia yang sudah terlanjur berparadigma positivistik-legalisti. Hal ini dikarenakan hukum progresif mengandung karakter antara lain: pertama, hukum progresif berpandangan hukum untuk manusia sehingga harus menjamin kebahagiaan manusia; kedua, hukum bukanlah institusi yang absolut, otonom, dan final melainkan merupakan realitas yang dinamis, bergerak dan berubah sesuai zamannya; ketiga, hukum progresif mengutamakan keadilan, pro rakyat dan anti diskriminasi serta anti anarkhi $^{21}$.

Walaupun seakan-akan sangat mengutamakan keadilan, konsep hukum progresif tetap tidak meninggalkan kepastian. Prof Satjipto rahardjo mengatakan Hukum harus dipahami sebagai institusi peraturan/undang-undang (normative), institusi sosial (sosiologis), sekaligus juga sebagai institusi keadilan (filosofis) $^{22}$.

Jadi para aparat penegak hukum harus berani menerapkan hukum sevara progresif karena pada hakikatnya hukum progresif ini tidak bertentangan dengan undang-undang, hanya ada kemauan dari aparat penegak hukum atau tidak.

${ }^{21}$ Yusriadi, Tebaran Pemikiran Kritis Hukum dan \& Masyarakat, Surya Pena Gemilang: 2011, halaman 37

${ }^{22}$ Satjipto Rahardjo dalam Yusriadi, Tebaran Pemikiran Kritis Hukum dan \& Masyarakat, Surya Pena Gemilang: 2011, halaman 32 
Apabila menggunakan cara pandang hukum progresif, kasus minah ini tidak perlu dibawa ke Pengadilan, akan tetapi cukup di selesaikan secara kekeluargaan. Apabila pihak perusahaan terus menuntut pihak kepolisian untuk tetap memproses, maka kepolisian harus berani menjadi juru penafsir hukum ang komperhenshif sehingga memberikan arahan kepada pihak perusahaan untuk tidak menuntut pemrosesan. Atau jika memang sudah tidak ada jalan lain selain dibawa ke jalur hukum, maka kasus seperti ini tidak perlu ada penahanan. Apalagi syarat subyektif penahanan mustahil tercapai. Apakah seorang minah, prita akan menghilangkan barang bukti, apakah akan melarikan diri seperti nazarudin atau tersangka-tersangka kakap yang lain. Sehingga sebenarnya tidak ada alasan subyektif untuk menahan prita dan minah.

Kedepan untuk meminimalisir penegakan hukum terhadap kasus-kasus seperti terulang maka perlu dilakukan pembenahan secara komperhenshif pada sistem hukum pidana di Indonesia. Pembenahan ini harus dilakukan terhadap semua komponen sistem hukum tersebut. menurut Lawrence M Friedman, sistem hukum terdiri dari 3 (tiga) komponen yaitu ${ }^{23}$ : (1) komponen substansi hukum, yaitu segala bentuk aturan-aturan hukum

${ }^{23}$ Esmi Warassih, Pranata Hukum Sebuah Telaah Sosiologis, Badan Penerit Undip: 2011, halaman 24 yang diberlakukan; (2) komponen strutur hukum, yaitu lembaga yang menciptakan hukum atau aparat penegak hukum yang akan memproses setiap orang yang melanggar aturan hukum; (3) komponen Kultur Hukum, yaitu budaya masyarakat dalam berhukum atau dapat diartikan sebagai nilai-nilai dalam masyarakat ${ }^{24}$.

Sehingga untuk melakukan pembenahan sistem hukum pidana di Indonesia harus dilakukan secara komperhenshif yang menyangkut semua komponen sistem substansi, sistem struktur dan sistem kultur. Pertama, pembenahan sistem substansi, dalam substansi banyak yang perlu dibenahi baik dalam hal aturan hukum materiil maupun formil serta penetensiernya. Dalam aturan hukum formil perlu memasukkan suatu pasal yang mencerminkan nilai keadilan dan kemanfaatan. Nilai keadilan dan kemanfaatan ini bisa terakomodiur apabila dalam aturan hukum mencantumkan tujuan pemidanaan. Selama ini sesuatu dikatakan dapat dipidana apabila sudah memenuhi rumusan delik yang terkenal dengan teori monistis, artinya suatu dikatakan tindak pidana apabila memenuhi rumusan delik dan padanya dapat dijatuhi pidana. Walaupun pada perkembangannya Prof. Moeljatno menawarkan sistem dualistis, artinya setiap orang tidak dapat dipidana apabila memenuhi rumusan delik dan adanya kesalahan dalam diri terdakwa.

${ }^{24}$ (Warassih, 2011: 24) 
Nampaknya dualistis ini mungkin memenuhi rasa keadilan akan tetapi nilai kemanfaatan belum didapatkan sehingga perlu adanya tujuan pemidanaan sebagai jembatan memperoleh nilai kemanfaatan. Dengan memasukkan unsur keadilan ini akhirnya memunculkan rumus baru dalam boleh dipidanya orang apabila memenuhi rumusan delik, adanya kesalahan dan tujuan pemidanaan tercapai. Apabila tidak memenuhi ketiga unsur tersebut, maka pidana tidak boleh dijatuhkan. Tiga unsur ini harus mulai diterapkan pada saat perkara masuk lembaga yang berwenang yaitu kepolisian, sehingga apabila tidak memenuhi ketiga unsur di atas, maka tidak perlu dilimpahkan ke penyidikan.

Kedua, pembenahan struktur hukum. Pembenahan dalam struktur hukum ini lebih menekankan pada perubahan dalam lembaga penegak hukum (kepolisian, kejaksaan, dan pengadilan). Penegak hukum harus diberi kebebasan untuk menafsirkan hukum sesuai dengan nilainilai keadilan, bukan hanya sebagai corong undang-undang (la bouche de la loi). Untuk mewujudkan aparat yang seperti ini, maka perlu adanya pembenahan menyeluruh dari aparat penegak hukum terutama dalam aspek sumber daya manusianya. Polisi kedepan minimal harus berpendidikan S1, jaksa dan hakim minimal berpendidikan S2. Dengan pembenahan tingkat pendidikan ini diharapkan pola fikir progresif.
Ketiga, pembenahan dalam kultur hukum. Pembenahan ini lebih pada kepedulian masyarakat terhadap budaya berhuku. Masyarakat adalah faktor penting dalam efektifnya suatu substansi hukum karena untuk kepentingan masyarakatlah hukum ini dibuat. Sehingga masyarakat harus terus diberikan pemahaman yang komperhenshif perihal hukum, sehingga apabila ada pelanggaran hukum masyarakat ikut berpartisipasi, begitu juga sebaliknya, jika terjadi kesewenang-wenangan hukum maka masyarakat bisa melakukan control balik.

\section{F. SIMPULAN}

Hukum bukanlah suatu hal yang mati akan tetapi hukum selalu bergerak dinamis dan mengikuti perkembangan zaman. Kasus-kasus kecil seperti kasus minah dan prita adalah contoh kecil dari liarnya penegakan hukum berparadigma positivistik legalistik tanpa ada yang bisa mengendalikan bahkan pemikiran positivistik legalistik ini telah mengakar pada hakim sebagai aparat pemutus pada peradilan.

Secara hukum positif, polisi, jaksa, dan hakim tidak dapat dipersalahkan karena hanya memenuhi rumusan Undang-Undang yang tidak memberikan kesempatan pada aparat penegak hukum untuk berbuat sesuai nurani. Walaupun hakim diberi kebebasan sesuai hati nurani akan tetapi apabila terbentur dengan bukti yang sudah lengkap, 
tidak alas an bagi hakim untuk memutuskan. Disisi lain masyarakat sebagai obyek hukum merasa terusik rasa keadilannya dengan keputusan hakim yang menyatakan minah dan prita bersalah. Sehingga perlu dilakukan upaya penegakan hukum progresif dan dibarengi dengan pembenahan sistem hukum pidana baik dalam segi substansi, struktur maupun budaya hukum.

\section{DAFTAR PUSTAKA}

\section{a. Buku :}

Rachman, Maman dkk., 2003. Filsafat Ilmu, Semarang: UPT MKU Universitas Negeri Semarang.

Rahardjo, Satjipto dkk., 2008. Hukum Progresif Sebagai Dasar pembangunan Ilmu Hukum Indonesia dalam buku Menggagas Hukum Progresif Indonesia, Yogyakarta-Semarang: diterbitkan atas kerjasama Pustaka pelajar, IAIN Walisongo, dan Program Doktor Undip.
1986. Ilmu Hukum, Bandung: Penerbit Alumni.

Unger, Roberto M., 2010. Teori hukum Kritis, Bandung: Penerbit Nusa Media

Marwan, Awaludin, 2010. Teori Hukum Kontemporer Suatu Pengantar Posmodernisme Hukum, Yogyakarta: Penerbit rangkang Education.

Masyhar, Ali, 2008 Pergulatan Kebijakan Hukum Pidana dalam Ranah Tatanan Sosial, Semarang: Unnes Press.

Moeljatno, 2002. Asas-asas Hukum Pidana, Jakarta: PT. Rineka Cipta.

Warassih, Esmi, 2010. Paranata Hukum dalam Telaah Sosiologis, Semarang: Badan penerbit Undip.

Yusriadi, 2010. Tebaran pemikiran Kritis Hukum dan masyarakat, Malang: Surya Pena Gemilang Publising,

\section{b. Undang-Undang}

Kitab Undang-Undang Hukum Acara Pidana, Surabaya: Penerbit Karya Anda

Kitab Undang-Undang Hukum Pidana, terjemahan dari Prof. Moelyatno, 2009, Jakarta: Bumi Aksara, 